\title{
Knowledge, Attitude and Practice of Health Care Professionals towards Covid-19 and Associated Factors at Public Health Facilities of Sidama Region, Ethiopia
}

\section{Sisay Dejene Babulo ( $\sim$ sisaydej19@gmail.com )}

Hawassa University College of Medicine and Health Sciences https://orcid.org/0000-0001-7728-7183

\section{Ezedin Molla}

Medicines Inspectorate: Medicines and Healthcare Products Regulatory Agency

\section{Ephrem Geja}

College of Medicine and Health Sciences, Hawassa University, Ethiopia

\section{Emnet Tesfaye}

College of Medicine and Health Sciences, Hawassa University, Ethiopia

\section{Yilikal Simachew}

College of Medicine and Health Sciences, Hawassa University, Ethiopia

Amanuel Ejeso

College of Medicine and Health Sciences, Hawassa University, Ethiopia

\section{Zewdie Oltaye}

College of Medicine and Health Sciences, Hawassa University, Ethiopia

\section{Nana Chea}

Medicines and Healthcare Products Regulatory Agency

\section{Ephrem Lejore}

College of Medicine and Health Sciences, Hawassa University, Ethiopia

\section{Negash Tagese}

College of Medicine and Health Sciences, Hawassa University, Ethiopia

\section{Seife Kibru}

College of Medicine and Health Sciences, Hawassa University, Ethiopia

\section{Research}

Keywords: Knowledge, Attitude, Practice, COVID-19, Sidama

Posted Date: December 28th, 2021

DOI: https://doi.org/10.21203/rs.3.rs-1166007/v1 
License: (c) (i) This work is licensed under a Creative Commons Attribution 4.0 International License. Read Full License 


\section{Abstract}

Background: As the World Health Organization situation report of November 14, 2021, globally there were over 252 million confirmed cases and over 5 million deaths attributable to the COVID-19 pandemic. How COVID-19 is transmitted put health care professionals (HCPs) at higher risk of contracting the disease because of their work conditions. Information regarding knowledge, attitude, and practice (KAP) towards the disease among HCPs are of higher importance to devise interventions that will tackle the pandemic.

Methods: A facility based cross-sectional study was conducted from September 29 to October 07, 2020, among randomly selected 422 health care professionals. Epi-data and SPPS software were used for entry and analysis of the data respectively. Frequencies, percentages, and charts were used to describe the KAP of HCPs towards the disease. Binary logistic regression was conducted to identify factors that are associated with the KAP of HCPs. Variables with a p-value less than 0.05 were declared as significantly associated.

Results: 406 HCPs have participated in this study. Less than half (45\%) HCPs had sufficient knowledge about COVID-19. HCPs aged 30 or more years, working in health centers, and HCPs that received an orientation or training regarding COVID-19 had significantly higher knowledge. About $77 \% \mathrm{HCPs}$ had a positive attitude towards COVID-19. Educational level and knowledge about COVID-19 were significant predictors of attitude. About three-fifths (59\%) of study participants had good practice towards COVID-19. Types of health facilities, work experience, and orientation or training status were significantly associated with the practice.

Conclusion: This study found a low proportion of HCPs having sufficient knowledge about COVID-19. About four in ten HCPs had poor practice towards COVID-19. Training, monitoring and supervision, knowledge and skill-sharing activities should be given due emphasis to tackle the pandemic in the region.

\section{Background}

In December 2019, a cluster of patients with pneumonia of unknown origin was identified in Wuhan, Hubei Province, China. Most of the patients had a history of visiting Huanan Seafood Wholesale Market, which trades in fish and a variety of live animal species including poultry, bats, marmots, and snakes. The Chinese Center for Disease Control and Prevention (China CDC) and Wuhan City health authorities reported an epidemic of pneumonia of unknown causes in Wuhan City on December 31, $2019(1,2)$. The causative agent was identified from throat swab samples conducted by the China CDC on 7th January 2020 and was subsequently named Severe Acute Respiratory Syndrome Coronavirus 2 (SARS-CoV-2). Later on, World Health Organization (WHO) named the disease coronavirus disease 2019 (COVID-19) on 11 February 2020 (3).

As the World Health Organization situation report of November 14, 2021, globally there were over 252 million confirmed cases and over 5 million deaths attributable to the COVID-19 pandemic (4). Based on 
the center of disease control and prevention (CDC), coronavirus spreads mainly from person to person by close contact (within about 2 meters) with infected people via respiratory droplets (through coughing or sneezing) or transmitted by touching a surface or object that the virus on it (5). How COVID 19 transmitted put health care professionals (HCPs) at higher risk of contracting the disease because of their work conditions. Every day in hospitals, health centers, home care settings, within the community and other places health care professionals meet with people to provide a variety of health services. Thus, they are exposed to this pandemic while executing their unavoidable responsibility and providing selfless service.

There is limited information describing the global number of HCWs infected by COVID-19; which might be due to a lack of reporting trend of the disease by profession. However, the number of HCPs acquired the disease were reported to CDC - the USA from the country's states. The report has shown that 9,282 HCWs (19\% of total cases) were confirmed to have the disease and 27 died within the period February 12 to April 9, 2020. More than half of these HCPs had contact with COVID-19 patients in health care settings while others met the patients in households and communities (6). It is well known that HCPs' knowledge about a certain disease can influence their attitudes and practices. And also it can be predicted that incorrect attitudes and practices will lead to an increment in the risk of acquiring an infection (7).

Provision of health care during this highly transmittable pandemic is the responsibility of the HCPs. Because HCPs frequently contact patients infected with COVID-19, it poses a serious occupational health risks to the professionals (8). During epidemics protecting HCPs and preventing transmission of infections within the hospitals are vital actions. In turn, this requires that HCPs must have updated knowledge regarding the source, transmission, symptoms, and preventive measures of disease (9). Globally, some studies have been conducted to assess health care professionals' knowledge, attitudes, and practices (KAP) towards COVID-19, and most of them were done in hospital settings (10-13). The study conducted in Jordan has indicated only $36.1 \%$ of dentists reported that the incubation period of COVID-19 is 1-14 days but the majority of professionals were aware of symptoms (10).

The studies conducted concerning KAP of COVID-19 among HCPs did not address the professionals in rural health care settings especially health centers which are near to the majority of the population in many countries. As we know more than $80 \%$ of the Ethiopian population reside in a rural areas where health centers are in proximity providing both preventive and curative services. Public health officers, nurses, midwives, pharmacists, laboratory technicians are varieties of HCPs in most health centers. All of these professionals have direct contact with their patients in their day-to-day activities. A single infected HCP in a health center can transmit the disease to their patients and colleagues which further spread to the community. To date, there is no information regarding knowledge, attitudes, and practices towards COVID-19 among HCPs in Ethiopia including Sidama National Regional State. This study was aimed at determining the KAP of COVID-19 and associated factors among HCPs in Sidama National Regional State.

\section{Materials And Methods}




\section{Study design and setting}

Facility-based cross-sectional study design was implemented in this study. It was conducted in public health facilities of Dalle, Shebedino, Aleta Wondo, and Hawassa Zuria districts of Sidama National Regional State (SNRS). Being one of the administrative regions of Ethiopia, SNRS is located $272 \mathrm{~km}$ to the southeast of Addis Ababa, the capital city of Ethiopia. Currently, there were 15 public hospitals, 126 health centers, 531 health posts, 24 medium, and 83 primary private and 7 Non-Governmental Organizations (NGO) clinics. There were a total of one general hospital, 3 primary hospitals, and 23 health centers in the selected four districts.

\section{Study subjects and sampling}

Different categories of health care professionals (nurses, physicians, public health officers, midwives, druggists/pharmacists, laboratory technicians, and others) working in diverse departments have participated in the study. All public health facilities in four districts were included and an attempt was made to involve all departments in the facilities. The sample size for the study was estimated by assuming a $50 \%$ proportion of HCPs having sufficient knowledge due to the lack of similar studies in the comparable settings. We calculated the sample needed for the survey to be 422 , assuming a $95 \%$ confidence interval, $5 \%$ precision, and $10 \%$ non-response rate. The total sample was divided into all health facilities proportionally based on the number of HCPs in the health facilities. The HCPs that agreed to participate and who responded with completed questionnaires were 406 , which is $96.2 \%$ of the total sample size.

\section{Measurement tool and data collection}

Regarding the data collection tool, the questionnaire was developed after conducting a review of several published pieces of research and Ethiopian and WHO COVID-19 management guidelines $(5,14-16)$. Data were collected using a close-ended, structured, and self-administered questionnaire from September 29 to October 09, 2020. A questionnaire with four sections (socio-demographic characteristics, knowledge, attitude, and practice items) was prepared and administered in English. A standardized questionnaire was distributed by six first-degree holder data collecting HCPs and completed by study participants inside their health care facilities.

For most of the knowledge items participants were asked to respond yes, no, or I don't know and for some questions, they were asked to choose the correct answer and fill the blank space based on the nature of items. The attitude items were responded to using a five-point Likert scale (strongly agree, agree, neutral, disagree, and strongly disagree). The responses for practice items were always, sometimes, and never. Precautions for reducing COVID-19 infection, particularly physical distancing, wearing a mask, and sanitizing hands were implemented during the data collection process.

\section{Operational definitions}


it was considered sufficient if the participant correctly answers $80 \%$ (score $=14.4$ or above) or more of knowledge questions; and insufficient knowledge when the score was below $80 \% .18$ items were used to assess knowledge of HCPs. To calculate knowledge score 1 and 0 points were given to correct and incorrect answers respectively.

\section{Attitude towards COVID-19}

it was considered positive attitude if the calculated score is equal to or greater than $80 \%$ (score $=32$ or above); and negative attitude when the score was below $80 \%$. 8 five-point Likert scale items were used to assess attitude scores. 5 to 1 points were given from strongly agree to strongly disagree responses in order.

\section{Practice towards COVID-19}

it was considered good practice if the participant correctly answers $80 \%$ (score $=21.6$ or above) or more of practice questions; and poor practice when the score was below $80 \% .9$ items were used to assess the practice of HCPs. 3, 2, and 1 points were given to always, sometimes, and never responses respectively.

The $80 \%$ cut-off point for knowledge, attitude, and practice was used based on Bloom's recommendation as used by another study $(16,17)$.

\section{Data management and analysis}

To ensure data quality, one-day training was given to data collectors. Then pretest was conducted on $5 \%$ of the total sample size at Millennium health center. Then, necessary modifications were made to the tool for final data collection. The collected data were checked every day by research team members for completeness and appropriateness.

The collected data were cleaned, coded, and entered into Epi-data version 3.1 then exported to and analyzed using SPSS version 21. For the knowledge questions with multiple responses, the options were entered and analyzed independently. Descriptive statistics (Frequencies, proportions, measures of central tendency, and measure of variation) were used to describe the study findings. Binary logistic regression analysis was conducted to identify factors associated with the KAP of COVID-19. The summary of the result was presented descriptively by frequency tables, graphs, and charts and analytically by adjusted odds ratio and confidence interval. Explanatory variables with p-value less than 0.05 were declared as significantly associated.

\section{Ethical Issues}

Ethical clearance was obtained from Hawassa University College of Medicine and Health Science (HUCMHS) Institutional Review Board. Support letter was obtained from the Research and Community Service Directorate of HU-CMHS and respective districts' health offices. Informed verbal consent was received from the participants after explaining the purpose of the study and confidentiality of data. Data were collected only from voluntary HCPs. 


\section{Results}

\section{Participants' Socio-demographic Characteristics}

From the total sample of four hundred twenty-two, 413 (response rate of $97.7 \%$ ) health care professionals have participated in this study. Among these respondents 7 incomplete questionnaires were discarded; thus, 406 responses were eligible for the analysis. Of the 406 participants, 239 (58.9\%) were male and the rest were female health care professionals. Their age ranged from 19-52 years with a mean of 28 (SD = 4.4) years. About 41 percent of the study participants had got training or orientation regarding COVID-19. The participants' characteristics are shown in the table below (Table 1).

\section{Table 1}

Socio-demographic characteristics of participants $(n=406)$ 


\begin{tabular}{|c|c|c|}
\hline Variable & Frequency & Percentage \\
\hline \multicolumn{3}{|l|}{ Sex } \\
\hline Male & 239 & 58.9 \\
\hline Female & 167 & 41.1 \\
\hline \multicolumn{3}{|l|}{ Age } \\
\hline$<30$ years & 283 & 70 \\
\hline$\geq 30$ years & 123 & 30 \\
\hline \multicolumn{3}{|l|}{ Marital status } \\
\hline Married & 225 & 55.4 \\
\hline Single & 179 & 44.1 \\
\hline Others & 2 & 0.5 \\
\hline \multicolumn{3}{|l|}{ Religion } \\
\hline Protestant & 261 & 64.3 \\
\hline Orthodox & 127 & 31.3 \\
\hline Muslim & 14 & 3.4 \\
\hline Other & 4 & 1 \\
\hline \multicolumn{3}{|l|}{ Type of health facility } \\
\hline Health center & 181 & 44.6 \\
\hline Primary hospital & 132 & 32.5 \\
\hline General hospital & 93 & 22.9 \\
\hline \multicolumn{3}{|l|}{ Profession } \\
\hline Nurse & 211 & 52 \\
\hline Public health officer & 66 & 16.3 \\
\hline Midwife & 35 & 8.6 \\
\hline Laboratory & 31 & 7.6 \\
\hline Medical doctor & 28 & 6.9 \\
\hline Pharmacy & 20 & 4.9 \\
\hline Other & 15 & 3.7 \\
\hline \multicolumn{3}{|l|}{ Educational level } \\
\hline First degree & 241 & 59.4 \\
\hline
\end{tabular}




\begin{tabular}{|lll|} 
Diploma & 160 & 39.4 \\
Other & 4 & 1 \\
\hline Work experience & & \\
Up to 5 years & 217 & 53.6 \\
6-10 years & 158 & 39 \\
$>10$ years & 30 & 7 \\
\hline Orientation and/or training on COVID-19 & & \\
Yes & & \\
No & 167 & 41.1 \\
& 239 & 58.9 \\
\hline
\end{tabular}

\section{Knowledge about COVID-19}

The mean knowledge score was $13.6(\mathrm{SD}=2.97)$. This mean score is $75.6 \%$ of the total score. Forty-five percent $(n=183)$ of the participants scored $80 \%$ or more and were considered to have sufficient knowledge regarding COVID-19. About 74 and 77 percent HCPs correctly responded incubation and quarantine periods respectively for COVID-19 (Table 2).

Table 2

Participants' response to knowledge questions towards COVID-19 $(n=406)$ 


\begin{tabular}{|c|c|c|}
\hline Knowledge items & Responses & $(\mathrm{N}, \%)$ \\
\hline \multirow[t]{4}{*}{$\begin{array}{l}\text { What are the free call center numbers to seek information about COVID- } \\
19 \text { in Ethiopia? }\end{array}$} & $\frac{952 \text { and/or }}{8335}$ & $\begin{array}{l}222 \\
(54.7)\end{array}$ \\
\hline & Other & 14 \\
\hline & Do not know & \\
\hline & & $\begin{array}{l}170 \\
(41.9)\end{array}$ \\
\hline \multirow[t]{2}{*}{ What type of microorganism is the causative agent of COVID-19? } & $\underline{\text { Virus }}$ & $\begin{array}{l}397 \\
(97.8)\end{array}$ \\
\hline & Other & $\begin{array}{l}9 \\
(2.2)\end{array}$ \\
\hline \multirow[t]{3}{*}{$\begin{array}{l}\text { How COVID-19 virus transmits from an infected person to an uninfected } \\
\text { person? }\end{array}$} & $\begin{array}{l}\text { Via respiratory } \\
\text { droplets }\end{array}$ & $\begin{array}{l}371 \\
(91.4)\end{array}$ \\
\hline & $\frac{\text { Via direct }}{\text { contact }}$ & $\begin{array}{l}265 \\
(65.3)\end{array}$ \\
\hline & Do not know & $\begin{array}{l}2 \\
(0.5)\end{array}$ \\
\hline \multirow[t]{4}{*}{$\begin{array}{l}\text { People infected with COVID-19, but have no symptoms can transmit the } \\
\text { virus to others }\end{array}$} & & $\begin{array}{l}238 \\
(58.6)\end{array}$ \\
\hline & & 128 \\
\hline & Do not know & $(31.5)$ \\
\hline & & $\begin{array}{l}40 \\
(9.8)\end{array}$ \\
\hline \multirow[t]{5}{*}{ What is the incubation period of COVID-19? } & $\begin{array}{l}\text { Less than } 7 \\
\text { days }\end{array}$ & $\begin{array}{l}21 \\
(5.2)\end{array}$ \\
\hline & $\underline{2-14}$ days & $\begin{array}{l}302 \\
(74.4)\end{array}$ \\
\hline & 2-21 days & \\
\hline & Do not know & $(17.2)$ \\
\hline & & $12(3)$ \\
\hline \multirow[t]{5}{*}{ What are the most common clinical manifestations of COVID-19? } & $\underline{\text { Fever }}$ & $\begin{array}{l}329 \\
(81)\end{array}$ \\
\hline & Drycough & 313 \\
\hline & Muscle pain & $(77.1)$ \\
\hline & Do not know & $\begin{array}{l}148 \\
(36.5)\end{array}$ \\
\hline & & $\begin{array}{l}7 \\
(1.7)\end{array}$ \\
\hline What is the scientific way of confirming the COVID-19 case? & By lab & 321 \\
\hline
\end{tabular}




\begin{tabular}{|c|c|c|}
\hline & investigation & $(79.1)$ \\
\hline & $\begin{array}{l}\text { Signs and } \\
\text { symptoms }\end{array}$ & $\begin{array}{l}18 \\
(4.4)\end{array}$ \\
\hline & By physical & $8(2)$ \\
\hline & Do not know & $\begin{array}{l}59 \\
(14.5)\end{array}$ \\
\hline $\begin{array}{l}\text { Supportive treatment can help most patients recover from the COVID-19 } \\
\text { infection }\end{array}$ & $\underline{\text { Yes }}$ & $\begin{array}{l}338 \\
(833)\end{array}$ \\
\hline & No & \\
\hline & Do not know & $(15)$ \\
\hline & & $\begin{array}{l}7 \\
(1.7)\end{array}$ \\
\hline For how long do you think people who have contact with someone & 5-10 days & 16 \\
\hline & 14 days & \\
\hline & 21 days & $(77.6)$ \\
\hline & Do not know & $\begin{array}{l}68 \\
(16.7)\end{array}$ \\
\hline & & $\begin{array}{l}5 \\
(1.2)\end{array}$ \\
\hline What are the preventive measures for COVID-19? & $\begin{array}{l}\text { Staying at } \\
\text { home }\end{array}$ & $\begin{array}{l}348 \\
(85.7)\end{array}$ \\
\hline & Wearing mask & $\begin{array}{l}334 \\
(82.3)\end{array}$ \\
\hline & $\begin{array}{l}\text { Physical } \\
\text { distancing }\end{array}$ & 312 \\
\hline & Hand washing & $\begin{array}{l}280 \\
(69)\end{array}$ \\
\hline $\begin{array}{l}\text { What is/are the correct measure/s if a health worker finds an individual } \\
\text { who has contact with a person infected with COVID-19? (encircle all }\end{array}$ & $\frac{\text { Immediate }}{\text { isolation }}$ & $\begin{array}{l}291 \\
(71.7)\end{array}$ \\
\hline & $\begin{array}{l}\text { Admitting the } \\
\text { patient }\end{array}$ & $\begin{array}{l}31 \\
(7.6)\end{array}$ \\
\hline & $\begin{array}{l}\text { Providing } \\
\text { symptomatic } \\
\text { treatment }\end{array}$ & $\begin{array}{l}13 \\
(3.2)\end{array}$ \\
\hline & Other & \\
\hline & Do not know & $(2.2)$ \\
\hline & & $\begin{array}{l}62 \\
(15.3)\end{array}$ \\
\hline
\end{tabular}




\section{Attitude towards COVID-19}

The mean attitude score was $34.3(S D=4.7)$. Seventy-seven percent $(n=313)$ of health care professionals (that had scored $80 \%$ and above of total attitude score) had a good attitude towards COVID-19. Only 47 percent healthcare professionals strongly agreed to receive COVID-19 vaccine when it became available. Only about 38 percent HCPs strongly agreed to work in COVID-19 care center if they are asked by the government Table 3.

Table 3

Participants' response for attitude items $(n=406)$

\begin{tabular}{|c|c|c|c|c|c|}
\hline Attitude statements & $\begin{array}{l}\text { SD }(n, \\
\%)\end{array}$ & $\begin{array}{l}D(n, \\
\%)\end{array}$ & $\underset{\%}{N}(n$, & $\begin{array}{l}A(n, \\
\%)\end{array}$ & $\begin{array}{l}\text { SA }(n \\
\%)\end{array}$ \\
\hline I am at risk of getting COVID-19 infection & $\begin{array}{l}19 \\
(4.7)\end{array}$ & $\begin{array}{l}15 \\
(3.7)\end{array}$ & $\begin{array}{l}19 \\
(4.7)\end{array}$ & $\begin{array}{l}131 \\
(32.3)\end{array}$ & $\begin{array}{l}222 \\
(54.7)\end{array}$ \\
\hline $\begin{array}{l}\text { I am scared of transmitting COVID-19 to my family } \\
\text { members }\end{array}$ & $\begin{array}{l}15 \\
(3.7)\end{array}$ & $\begin{array}{l}24 \\
(5.9)\end{array}$ & $\begin{array}{l}29 \\
(7.1)\end{array}$ & $\begin{array}{l}137 \\
(33.7)\end{array}$ & $\begin{array}{l}201 \\
(49.5)\end{array}$ \\
\hline $\begin{array}{l}\text { My daily life has been affected by the COVID-19 } \\
\text { pandemic }\end{array}$ & $11(2.7)$ & $\begin{array}{l}24 \\
(5.9)\end{array}$ & $\begin{array}{l}34 \\
(8.4)\end{array}$ & $\begin{array}{l}134 \\
(33)\end{array}$ & $\begin{array}{l}203 \\
(50)\end{array}$ \\
\hline COVID-19 is a serious disease & $2(0.5)$ & $\begin{array}{l}15 \\
(3.7)\end{array}$ & $\begin{array}{l}29 \\
(7.1)\end{array}$ & $\begin{array}{l}86 \\
(21.2)\end{array}$ & $\begin{array}{l}273 \\
(67.2)\end{array}$ \\
\hline $\begin{array}{l}\text { Staying at home, wearing masks, keeping } 2 \text { meters } \\
\text { distance, and frequent hand washing are effective } \\
\text { ways to prevent COVID-19 transmission }\end{array}$ & $3(0.7)$ & $\begin{array}{l}9 \\
(2.2)\end{array}$ & $\begin{array}{l}20 \\
(4.9)\end{array}$ & $\begin{array}{l}131 \\
(32.3)\end{array}$ & $\begin{array}{l}243 \\
(59.9)\end{array}$ \\
\hline $\begin{array}{l}\text { I will take the COVID- } 19 \text { vaccine when it is made } \\
\text { available }\end{array}$ & $\begin{array}{l}13 \\
(3.2)\end{array}$ & $\begin{array}{l}18 \\
(4.4)\end{array}$ & $\begin{array}{l}42 \\
(10.3)\end{array}$ & $\begin{array}{l}142 \\
(35)\end{array}$ & $\begin{array}{l}191 \\
(47)\end{array}$ \\
\hline $\begin{array}{l}\text { I am voluntary to work in a COVID-19 care center if } \\
\text { assigned by the government }\end{array}$ & $\begin{array}{l}11 \\
(2.7)\end{array}$ & $\begin{array}{l}21 \\
(5.2)\end{array}$ & $\begin{array}{l}41 \\
(10.1)\end{array}$ & $\begin{array}{l}178 \\
(43.8)\end{array}$ & $\begin{array}{l}155 \\
(38.2)\end{array}$ \\
\hline $\begin{array}{l}\text { If I have major symptoms associated with COVID-19 or } \\
\text { contact with COVID-19 infected individual, I am okay } \\
\text { to be quarantined }\end{array}$ & $6(1.5)$ & $\begin{array}{l}15 \\
(3.7)\end{array}$ & $\begin{array}{l}30 \\
(7.4)\end{array}$ & $\begin{array}{l}159 \\
(39.2)\end{array}$ & $\begin{array}{l}196 \\
(48.3)\end{array}$ \\
\hline
\end{tabular}

SD: Strongly Disagree, D: Disagree, N: Neutral, A: Agree, SA: Strongly Agree

\section{Practice towards COVID-19}

The mean practice score was 22.3 (SD: 3.3). Fifty-nine percent $(n=239)$ of health care professionals (that had scored $80 \%$ and above of total practice score) had good practice of COVID-19. Among the 
participants only 46.6 percent were responded that they avoid going to crowded places and only about 48 percent reported that they maintain physical distancing in their day to day activities (Table 4).

Table 4

Participants' response for practice items $(n=406)$

\begin{tabular}{|c|c|c|c|}
\hline Practice statements & $\begin{array}{l}\text { Never } \\
(n, \%)\end{array}$ & $\begin{array}{l}\text { Sometimes } \\
(n, \%)\end{array}$ & $\begin{array}{l}\text { Always } \\
(n, \%)\end{array}$ \\
\hline How often do you avoid going to crowded places? & $\begin{array}{l}21 \\
(5.2)\end{array}$ & $196(48.3)$ & $\begin{array}{l}189 \\
(46.6)\end{array}$ \\
\hline How often do you wear a mask when moving out of your home? & $\begin{array}{l}16 \\
(16.7)\end{array}$ & $152(37.4)$ & $\begin{array}{l}238 \\
(58.6)\end{array}$ \\
\hline $\begin{array}{l}\text { How often do you refrain from shaking hands, hugging, and } \\
\text { kissing people? }\end{array}$ & $\begin{array}{l}68 \\
(3.7)\end{array}$ & $130(32)$ & $\begin{array}{l}208 \\
(51.2)\end{array}$ \\
\hline $\begin{array}{l}\text { To prevent contracting and spreading COVID- } 19 \text {, how often do you } \\
\text { pay more attention to personal hygiene than usual? }\end{array}$ & $\begin{array}{l}9 \\
(2.2)\end{array}$ & $140(34.6)$ & $\begin{array}{l}256 \\
(63.2)\end{array}$ \\
\hline $\begin{array}{l}\text { How often do you wash your hands/use alcohol-based sanitizer } \\
\text { before and after handling patients? }\end{array}$ & $\begin{array}{l}6 \\
(1.5)\end{array}$ & $140(34.5)$ & $\begin{array}{l}260 \\
(64)\end{array}$ \\
\hline $\begin{array}{l}\text { How often do you practice physical distancing by remaining } 2 \\
\text { meters away from others when possible? }\end{array}$ & $\begin{array}{l}15 \\
(3.7)\end{array}$ & $195(48)$ & $\begin{array}{l}196 \\
(48.3)\end{array}$ \\
\hline $\begin{array}{l}\text { How often do you notify COVID-19 suspected case to the } \\
\text { appropriate authority when you encounter it? }\end{array}$ & $\begin{array}{l}13 \\
(3.2)\end{array}$ & $171(42.1)$ & $\begin{array}{l}222 \\
(54.7)\end{array}$ \\
\hline $\begin{array}{l}\text { How often do you follow a protocol for triage and isolation of } \\
\text { suspected COVID-19 cases in your workplace? }\end{array}$ & $\begin{array}{l}36 \\
(8.9)\end{array}$ & $176(43.3)$ & $\begin{array}{l}196 \\
(47.8)\end{array}$ \\
\hline $\begin{array}{l}\text { How often do you clean and disinfect frequently touched objects } \\
\text { and surfaces? }\end{array}$ & $\begin{array}{l}33 \\
(8.1)\end{array}$ & $170(41.9)$ & $\begin{array}{l}203 \\
(50)\end{array}$ \\
\hline
\end{tabular}

\section{Factors associated with knowledge, attitude, and practice towards COVID-19 among HCPs}

Factors associated with knowledge were age (AOR: 1.86; 95\%Cl: 1.13-3), educational level (AOR: 2.3; 95\%Cl: $1.46-3.65$ ), type of health facility (AOR: $0.35 ; 95 \% \mathrm{Cl}: 0.19-0.63$ ), and COVID-19 orientation and/or training (AOR: 1.6; 95\%Cl: 1.05 - 2.5). Educational level (AOR: 1.84; 95\% Cl: 1.1-3.0) and knowledge about COVID-19 (AOR: 4.7; 95\%Cl: 2.6-8.4) were associated with the attitude of the HCPs. Factors associated with the practice were COVID-19 training and/or orientation (AOR: 2; 95\% Cl: 1.3-3.2), working in primary hospitals (AOR: 4.3; 95\%Cl: 2.6-7.3), working in a general hospital (AOR: 2; 95\% Cl: 1.2-3.5), work experience in years (AOR: $1.8 ; 95 \% \mathrm{Cl}$ : 1.16-2.76) (Table 5). 
Table 5

Factors associated with knowledge, attitude, and practice of health care professionals towards COVID-19 $(n=406)$ 


\section{Knowledge}

Variables

Frequency $\operatorname{COR}(\mathrm{Cl})$

(\%)

AOR (Cl)

\section{Sex}

Male

239 (58.9) $1.6(1.1-2.5)$

$1.5(0.95-$

Female

$167(41.1) \quad 1$

2.2)

1

\section{Age}

$<30$

$283(69.7) \quad 1$

1

$\geq 30$

$123(30.3) \quad 1.5(0.96-2.2)$

$1.86(1.1-$

$3)^{*}$

\section{Educational level}

Diploma

$160(39.4) \quad 1$

1

First degree \& above

$245(60.3) \quad 1.9(1.3-2.9)$

2 (1.3-

$3.2)^{*}$

\section{Type of health facility}

Health center

Primary hospital

General hospital
$181(44.6) \quad 1$

$132(32.5)$

$93(22.9)$
1

$1.0(0.64-$

1.68)

$0.33(0.19-$

$0.58)^{\star}$

\section{Orientation and/or training}

on COVID-19

No

Yes

$\begin{array}{lll}239(58.9) & 1 & 1 \\ 167(41.1) & 1.6(1.1-2.4) & 1.6(1.03- \\ & & 2.39)^{\star}\end{array}$

\section{Attitude}

\section{Sex}

Male

Female

239 (58.9) $1.5(0.95-2.43)$

$167(41.1) \quad 1$

$1.4(0.85-$

2.3)

1

Age

$<30$ 


\section{Educational level}

Diploma

First degree \& above
$160(39.4) \quad 1$

245 (60.3) $2.1(1.3-2.4)$
1

$1.8(1.1-$

$3)^{\star}$

\section{Knowledge}

Insufficient

$220(54.6) \quad 1$

Sufficient

$183(45.4) \quad 4.6(2.6-8)$

4.7 (2.6-

$8.4)^{\star}$

\section{Practice}

\section{Type of health facility}

Health center

Primary hospital

General hospital
$181(44.6) \quad 1$

$132(32.5)$

93 (22.9)
$4.3(2.6-$

$7.3)^{*}$

$2(1.2-$
$3.5)^{*}$

\section{Educational level}

Diploma

$160(39.4) \quad 1$

1

First degree \& above

$245(60.3) \quad 1.7(1.1-2.5)$

$1.2(0.74-$

1.83)

Work experience

$\leq 5$ years

$217(53.4) \quad 1$

$\geq 6 y e a r s$

$188(46.3) \quad 1.6(1.05-2.34)$

\section{Orientation and/or training} on COVID-19

No

Yes

$\begin{array}{lll}239(58.9) & 1 & 1 \\ 167(41.1) & 2(1.4-3.2) & 2\left(1.3^{-}\right. \\ & & 3.2)^{\star}\end{array}$

Knowledge

Insufficient

$220(54.6) \quad 1$

1

Sufficient

$183(45.4) \quad 1.4(0.92-2.0)$

$1.3(0.84-$

2.0) 
1 = Reference category * = statistically significant variables

\section{Discussion}

COVID-19 is an emerging, rapidly changing global health challenge affecting all sectors. HCWs are not only at the forefront of the fight against this highly contagious infectious disease but are also directly or indirectly affected by it and the likelihood of acquiring this disease is higher among HCPs compared to the general population. It is of high significance that HCPs across the world have adequate knowledge about all aspects of the disease mainly clinical manifestation, diagnosis, proposed treatment, and established prevention strategies. As per our knowledge, this is the first study in Sidama National Regional State to assess the KAP of HCPs towards COVID-19. Globally, there are some studies documented the KAP of HCWs towards COVID-19.

In our study, we were able to demonstrate that about 5 in 10 HCPs had sufficient knowledge regarding COVID-19. We have found a mean knowledge score of $75.6 \%$ for questions about COVID-19 knowledge among HCPs working at public health facilities of Sidama National Regional State. This score is lower than the studies conducted among the US (80\%) (18) and Chinese (90\%) (19) general population. This difference may be due to the Chinese and US studies assessed COVID-19 symptoms using one direct question rather than asking the participants to choose from multiple options. In this study, it was found that only 45 percent of HCPs had sufficient knowledge concerning the cause, transmission, clinical manifestation, treatment, and prevention of COVID-19. This is lower than the proportion of HCPs with sufficient knowledge reported from Uganda (69\%) (16). This difference may be attributable to more items used to assess COVID-19 knowledge in this study.

According to this study, older HCPs ( $\geq 30$ years) were more likely to have sufficient knowledge contrary to Ugandan findings (16) where younger HCPs were more knowledgeable. This might be because of prompt attention given by older HCPs to COVID-19 related information. HCPs working in health centers were more knowledgeable compared to those work in a general hospital. This might be due to higher attention given to health centers concerning their proximity to the community. HCPs that got an orientation or training on COVID-19 were more likely to have sufficient knowledge than those who did not. This implies pieces of training on COVID-19 is necessary to enhance knowledge of HCPs. Sex of HCPs did not significantly associate with knowledge about COVID-19.

In this study, a mean attitude score of $85.8 \%$ was obtained on questions about COVID-19 attitude among HCPs working at public health facilities. It was revealed that 77 percent of participants had a positive attitude toward COVID-19. This is lower than the Vietnamese finding (93.3\%) (20) but much higher than the Ugandan study (21\%) (16). Generally, the majority of HCPs had a positive attitude towards COVID- 19. About 61 percent of HCPs said the preparation of their facilities to prevent COVID-19 is good. Only nearly half $(55 \%)$ of HCPs reported that Ethiopia will control COVID-19. Health Care Professionals whose educational level is first degree and above were more likely to have a positive attitude. Knowledge about 
COVID-19 was a significant predictor of attitude as the study conducted in Vietnam (20). Sex and age of HCPs were not significantly associated with attitude towards COVID-19.

About six in ten HCPs had good practice in our study. HCPs working in primary hospitals, as well as a general hospital, were more likely to have good practice than that work in health centers. HCPs that had six and more years of work experience had good practice as compared to counterparts. This study had also found that HCPs that attended orientation or training about COVID-19 had a good practice. Educational level, knowledge about COVID-19, and attitude towards COVID-19 were not significant predictors of COVID-19 practice.

\section{Limitations}

This study had some limitations. Firstly, the practice of HCPs was not observed rather it was filled by them; which may mask the actual practice. Secondly, since there was no standardized tool to assess the KAP of healthcare professionals we have adapted the questionnaire from WHO and Ethiopian COVID-19 management guidelines and some surveys $(5,14-16)$. Thirdly, the survey was conducted in only four districts of Sidama regional state and the results may not reflect the KAP of HCPs in the entire country.

\section{Conclusion}

We found that less than half of the study participants had sufficient knowledge about COVID-19 in Sidama regional state public health facilities. Knowledge about COVID-19 was significantly higher among HCPs aged 30 or more years, working in health centers, and HCPs that received an orientation or training regarding COVID-19. More than three fourth of HCPs had a positive attitude towards COVID-19. HCPs with an educational level of degree or more and had sufficient knowledge were more likely to have a positive attitude. About three-fifths of HCPs had good practice regarding COVID-19 in our study. The type of public health facility, work experience, and COVID-19 orientation or training status were statistically significant predictors of practice towards COVID-19.

We suggest regional health bureau and partners train health care professionals regarding the pandemic. Then, they need to supervise and monitor the overall COVID-19 control activities performed by HCPs in the public health facilities. Public health facilities need to facilitate knowledge and experience sharing among the trained and untrained HCPs in their organization. It will also be good if the HCPs also update themselves regarding COVID-19 through different information sources.

\section{Abbreviations}

AOR: Adjusted Odds Ratio; CDC: Centers for Disease Control and Prevention; COR: Crude Odds Ration; HCPs: Health Care professionals; HU-CMHS: Hawassa University College of Medicine and Health Sciences; KAP: Knowledge, Attitude, and Practice; NGO: Non-Governmental Organization; SD: Standard Deviation; SNRS: Sidama National Regional State; SPSS: Statistical Package for Social Sciences; USA: United States of America; WHO: World Health Organization; 


\section{Declarations}

\section{Ethics Approval and Consent to Participate}

This study was ethically approved by Hawassa University College of Medicine and Health Sciences Institutional Review Board (IRB/291/12). Informed verbal consent was received from study participants following an explanation of the survey purpose.

\section{Consent for publication}

Not applicable

\section{Availability of data and materials}

The datasets used and analyzed for this study are available from the corresponding author on reasonable request.

\section{Competing interests}

The authors declare that they have no competing interests.

\section{Funding}

The study was funded by Hawassa University.

\section{Authors' Contributions}

All authors contributed to the conceptualization of the study. SD, YS, EM, and AE coordinated the data collection process. The original draft was written by SD. The subsequent review of the report and manuscript revision was done by all authors.

\section{Acknowledgements}

We extend our gratitude to Hawassa University for their support in the whole course of the study. We are very thankful for the healthcare professionals who sincerely participated in the study. 


\section{References}

1. Lu H, Stratton CW, Tang YW. Outbreak of pneumonia of unknown etiology in Wuhan, China: The mystery and the miracle. J Med Virol. 2020;92(4):401-2.

2. WHO. World Health Organization. (2020). Novel Coronavirus (2019-nCoV): situation report, 1. World Health Organization. Vol. 205, World Health Organization. 2020.

3. WHO. WHO Director-General's remarks at the media briefing on 2019-nCoV on 11 February 2020. World Health Orgnatization (WHO). 2020.

4. WHO. COVID-19 weekly epidemiological update. World Heal Organ [Internet]. 2021;(58):1-23. Available from: https://www.who.int/publications/m/item/covid-19-weekly-epidemiological-update

5. WHO. Clinical management of COVID-19. Interim Guidance. May 2020. World Health Organization;

6. Burrer SL, de Perio MA, Hughles MM, Kuhar DT, Luckhaupt SE, McDaniel CJ et al. CDC COVID-19 Response Team. Characteristics of Health Care Personnel with COVID-19 - United States, February 12-April 9, 2020. Centers for Disease Control and Prevention. Mmwr. 2020;69(15):477-81.

7. McEachan R, Taylor N, Harrison R, Lawton R, Gardner P, Conner M. Meta-Analysis of the Reasoned Action Approach (RAA) to Understanding Health Behaviors. Ann Behav Med [Internet]. 2016;50(4):592-612. Available from: http://dx.doi.org/10.1007/s12160-016-9798-4

8. Gan WH, Lim JW, Koh D. Preventing Intra-hospital Infection and Transmission of Coronavirus Disease 2019 in Health-care Workers. Saf Health Work [Internet]. 2020;11(2):241-3. Available from: https://doi.org/10.1016/j.shaw.2020.03.001

9. Nemati M, Ebrahimi B, Nemati F. Assessment of iranian nurses' knowledge and anxiety toward covid19 during the current outbreak in iran. Arch Clin Infect Dis. 2020;15(COVID-19).

10. Khader Y, Al Nsour M, Al-Batayneh OB, Saadeh R, Bashier H, Alfaqih M, et al. Dentists' awareness, perception, and attitude regarding COVID-19 and infection control: Cross-sectional study among Jordanian dentists. JMIR Public Heal Surveill. 2020;6(2).

11. M. Salazar, J. Barochiner WE el. E. Since January 2020 Elsevier has created a COVID-19 resource centre with free information in English and Mandarin on the novel coronavirus COVID-. Ann Oncol [Internet]. 2020;(January):2-5. Available from:

https://www.ncbi.nlm.nih.gov/pmc/articles/PMC7254017/pdf/main.pdf

12. Shi Y, Wang J, Yang Y, Wang Z, Wang G, Hashimoto K, et al. Knowledge and attitudes of medical staff in Chinese psychiatric hospitals regarding COVID-19. Brain, Behav Immun - Heal [Internet]. 2020;4(March):100064. Available from: https://doi.org/10.1016/j.bbih.2020.100064

13. Paul Scheel. D. Since January 2020 Elsevier has created a COVID-19 resource centre with free information in English and Mandarin on the novel coronavirus COVID-. Ann Oncol. 2020; (January):19-20.

14. Erfani A, Shahriarirad R, Ranjbar K, Mirahmadizadeh A, Moghadami M. Knowledge, attitude and practice toward the novel coronavirus (COVID-19) outbreak- A population-based survey in Iran. Bull World Health Organ. 2020;(March):2-3. 
15. FMOH E. Covid19 Management Handbook. FMOH, Ethiop First Ed April 2020 [Internet]. 2020; (April):7-9. Available from: https://www.worldometers.info/coronavirus/?\%3D\%3D

16. Olum R, Chekwech G, Wekha G, Nassozi DR, Bongomin F. Coronavirus Disease-2019: Knowledge, Attitude, and Practices of Health Care Workers at Makerere University Teaching Hospitals, Uganda. Front Public Heal. 2020;8(April):1-9.

17. Kaliyaperuma K. Guideline for Conducting a Knowledge, Attitude and Practice (KAP) Study. Community Ophthalmol. 2004;IV(1).

18. Clements JM. Knowledge and behaviors toward COVID-19 among US residents during the early days of the pandemic: Cross-sectional online questionnaire. JMIR Public Heal Surveill. 2020;6(2):1-20.

19. Zhong BL, Luo W, Li HM, Zhang QQ, Liu XG, Li WT, et al. Knowledge, attitudes, and practices towards COVID-19 among chinese residents during the rapid rise period of the COVID-19 outbreak: A quick online cross-sectional survey. Int J Biol Sci. 2020;16(10):1745-52.

20. Huynh G, Nguyen T, Tran V, Vo K, Vo V, Pham L. Knowledge and attitude toward COVID-19 among healthcare workers at District 2 Hospital, Ho Chi Minh City. Asian Pac J Trop Med. 2020;13(6):260-5. 